\title{
Silicon in wheat crop under water limitation and seed tolerance to water stress during germination ${ }^{1}$
}

\author{
Guilherme Fontes Valory Gama ${ }^{2 *} \mathbb{D}$, Laryssa Bitencourt Teixeira Lima Brum², Maycon Silva Martins ${ }^{2}$, \\ Laércio Junio da Silva², Denise Cunha Fernandes dos Santos Dias ${ }^{2}$
}

10.1590/0034-737X202168040014

\begin{abstract}
Water stress during wheat seed germination and seedling establishment for affect the percentage and speed of germination. Silicon $(\mathrm{Si})$ is related to plant tolerance to different types of stress, then the application of this nutrient in the mother plant during seed production could contribute to the improvement of the seed quality and, consequently, its tolerance to stress. The aim was to evaluate the effect of foliar application of silicon on the tolerance of wheat seeds, produced under different irrigation levels, to water stress during germination and initial seedling growth. Wheat seeds were produced under three irrigation depths $(0,50$ and $100 \%$ of the total required irrigation) applied after the anthesis. The silicon was supplied in two doses by foliar application ( 0 and $5 \mathrm{mM}$ of $\mathrm{Si}$ ). The germination and seedling growth were performed under water stress induced by PEG 6000 at the $-0.2 ;-0.4 ;-0.6 \mathrm{MPa}$ osmotic potentials. In addition, in the control only distilled water was used. The reduction of the osmotic potential reduced seed germination, germination speed and seedling growth. Irrigation depths, as well as foliar application of $\mathrm{Si}$, during seed production did not influence the physiological quality and tolerance of seeds to water stress during germination.
\end{abstract}

Keywords: Triticum aestivum L.; seeds quality; seeds vigor; abiotic stress.

\section{INTRODUCTION}

Water stress occurs in large extensions of cultivable areas (Nogueira et al., 2001; Girotto et al., 2012) and for many crops can affect the water relations of plants metabolism, leading to reduced plant production.

In Brazil, the water deficit in wheat crop (Triticum aestivum $\mathrm{L}$.) occurs in a significant way in the northern regions of the Paraná state, towards the center of the country, which limits the cultivation of this cereal in certain regions of the Brazilian Cerrado (Monteiro, 2009; Andrade et al., 2015). In these regions, wheat crops under dry farming conditions may face water shortages. In addition to reducing the final yield, due to the occurrence of water deficit during the booting growth stage, this stress also contributes to failure on grain formation and inefficient filling of the grains. Also, it can affect the emergence and establishment of the crop, as the sowing stage occurs in the months of March and April (Monteiro, 2009), when in general there is a low rainfall occurrence.

Seed germination is a crucial stage in the establishment of crops and may be influenced by several abiotic stresses, including drought stress (Hubbard et al., 2012). For the germination process to take place, water availability is crucial for the activation of the chemical reactions involved in the metabolism and, therefore, generate the resumption of embryonic axis growth (Marcos-Filho, 2015). Thus, the reduction of the osmotic potential caused by water deficiency leads to a reduction in the percentage and speed of seed germination (Pereira \& Lopes, 2011), as well as a significant reduction in seedling growth (Kashif, 2011).

Several authors reported the effect of water stress during seed germination on the germination rate and seedling growth in wheat, with reductions in the length

\footnotetext{
Submitted on April 24th, 2019 and accepted on June $21^{\text {th }}, 2021$.

${ }^{1}$ This work is part of the first author's master's thesis

${ }^{2}$ Universidade Federal de Viçosa, Departamento de Agronomia, Viçosa, Minas Gerais, Brazil. guilhermefontes.gama@gmail.com; laryssa11brum@gmail.com; maycon.martins@ufv.br; laerciojdsilva@gmail.com; dcdias@ufv.br

*Corresponding author: guilhermefontes.gama@gmail.com
}

Rev. Ceres, Viçosa, v. 68, n.4, p. 360-367, jul/aug, 2021 
and dry weight of shoot and root (Dhanda et al., 2004; Rauf et al., 2007; Yagmur \& Kaydan, 2008), and in the final crop yield.

Silicon ( $\mathrm{Si}$ ) is a beneficial element for higher plants. Its effect is observed in situations of multiple stresses. When absorbed, it is accumulated in organs such as leaves and stems and forms a double layer structure composed of silica $\left(\mathrm{SiO}_{2}\right)$, which is deposited in the cuticle and acts in a structural way. It also influences the physiology and metabolism of plants, with increased antioxidant power (Tripathi et al., 2017; Bukhari et al., 2015). Its main effect under water deficit condition is the reduction of excessive water loss through the process of transpiration of plants (Rao et al., 2019).

This element plays an important role in plants, mainly of the Poaceae family, such as wheat, contributes to increase in growth and plant production, indirectly caused by upright leaves, decreased self-shading, and greater structural rigidity of the tissues (Sarto et al., 2014), besides generating some protection against abiotic (Khan et al., 2021) and biotic (Acevedo et al., 2021) stresses. Wheat plants that received foliar application of $\mathrm{Si}$ produced seeds with higher mass (Toledo et al., 2012). Although the effect on seed physiological quality has not been observed (Toledo et al., 2012; Segalin et al., 2013), it is expected that greater tolerance of the plants to the stresses contribute to the production of seeds with higher physiological quality under these conditions.

During the process of seed maturation, the environment is determinant for its physiological quality. Thus, abiotic stresses, such as water deficit, can reduce the quality of seed (Eskandari \& Alizadeh-Amraie, 2017). On the other hand, some studies reported the increase of the tolerance of the seeds to certain stresses, conditioned by the effect of the environment where the maturation process occurred (Bilichak \& Kovalchuk, 2016). According to Walter et al. (2011), in some grasses this effect can be observed, in such a way that plants that undergo cycles of water deficit present protection responses when again submitted to water shortage situations. Thus, seeds produced under conditions of water deficit could have a greater tolerance to this stress.

Thus, the objective of the present work was to evaluate the effect of foliar application of silicon on the tolerance of wheat seeds, produced under different irrigation depths, to water stress during germination and initial seedling growth.

\section{MATERIALAND METHODS}

The research was carried out in the Laboratory of Seed Analysis of the Department of Plant Science of the Federal University of Viçosa (Portuguese acronym: UFV).
Wheat seeds from cultivar BRS 264 were used. The seeds were produced under field conditions from April to August 2017, in Viçosa, MG. Acidity regulation and fertilization were performed based on the soil analysis, and the amount of acidity regulator and fertilizer as recommended by $\mathrm{Ri}$ beiro (1999). The climatic conditions during the production of the wheat seeds are presented in Figure 1.

During the seed production, the plants were submitted to different irrigation depths from the anthesis, with or without foliar application of Si. The experimental plots consisted of five rows of plants, spaced 0.20, ten meters in length. The useful area considered for application of the treatments comprised the total area occupied by plants in the three central lines minus 0.20 $\mathrm{m}$ at the ends. Irrigation treatments consisted of the application of three depths, 0,50 and $100 \%$ of the total irrigation required for the crop (ITN), calculated by means of the ratio between the actual irrigation required for the crop (IRN) and the efficiency of the irrigation system. It was used a drip irrigation system.

IRN was calculated by means of the water balance of the system, with information about the entrance (irrigation + precipitation) and exit (crop evapotranspiration - ETc) of water. For the calculation of ETc, the following equation was used (Allen et al., 1998):

$\mathrm{ETc}=\mathrm{ETo} \times \mathrm{Kc}$

In which: ETc - crop evapotranspiration in $\mathrm{mm} \mathrm{day}^{-1}$;

ETo - reference evapotranspiration in $\mathrm{mm} \mathrm{day}^{-1}$;

$\mathrm{Kc}$ - coefficient of the crop, dimensionless.

Estimates of crop evapotranspiration were performed using the Penman-Monteith-FAO 56 method (Allen et al., 1998). The values of Kc, as obtained by Libardi \& Costa (1997), used for each stage of the crop were: establishment, 0.29 ; tillering, 0.36 ; booting growth, 0.79 ; flowering, 1.11 ; grain formation, 1.16; and maturation, 0.45 . The meteorological data used for the calculations were obtained through the Meteorological Station of Automatic Surface Observation of Viçosa-MG (Estação Meteorológica de Observação de Superfície Automática de Viçosa - MG), with access by the National Institute of Meteorology (Instituto Nacional de Meteorologia - INMET). The daily data of temperature $\left({ }^{\circ} \mathrm{C}\right)$, relative humidity $(\%)$, dew point $\left({ }^{\circ} \mathrm{C}\right)$, pressure $(\mathrm{hPa})$, wind speed $\left(\mathrm{m} \mathrm{s}^{-1}\right)$, radiation $\left(\mathrm{kJm}^{2}\right)$ and rainfall $(\mathrm{mm})$ were accessed.

The plants throughout the experiment were irrigated in a four-day shift. Up to the anthesis event, when $50 \%$ of the plants in field were with the anthers open, all plants were irrigated with $100 \%$ of ITN. From the anthesis, the plants were submitted to the different irrigation depths.

For the foliar application of silicon, the commercial product Supa Silica ${ }^{\circledR}$ (Potassium Silicate $-\mathrm{K}_{2} \mathrm{SiO}_{2}$ ), with 
$25.7 \%$ of $\mathrm{SiO}_{2}$ and $12.23 \% \mathrm{~K}_{2} \mathrm{O}$ was used. The silicon treatments consisted in the application of two doses, 0 $\mathrm{mM}$ and $5 \mathrm{mM}$ of silicon, which were applied at the tillering stage, at 25 days after sowing (DAS). The application was performed with the aid of a system composed of a pressurized cylinder with $\mathrm{CO}_{2}$ and a double bar of type TT 11002 that provided a constant pressure of 3 bars and a volume of syrup of $260 \mathrm{~L} \mathrm{ha}^{-1}$.

At 110 days after sowing (DAS), when the plants were already dry, the spikes were harvested manually, which were threshed with the help of an experimental thresher. The seeds were dried naturally in the shade in a laboratory environment, untill 12\% moisture content. Each field plot was collected separately and constituted a laboratory repetition in the tests to evaluate the tolerance of the seeds to water deficit. The following evaluations were carried out:

\section{Germination}

Four replicates of 50 seeds were distributed on paper towel moistened with 2.5 times the dry paper weight with polyethylene glycol 6000 (PEG 6000) solutions equivalent to the osmotic potentials of $-0.2 ;-0.4$ and $-0.6 \mathrm{MPa}$ (Villela et al., 1991). The rolls were kept in germinator regulated at $20{ }^{\circ} \mathrm{C}$. In the control treatment, the paper towel was only moistened with distilled water. The evaluations consisted of daily counting of the number of normal seedlings until the values stabilized. With the data, the final germination percentage was calculated on the eighth day after sowing, and the first germination test count, on the fourth day after sowing (Brasil, 2009). The average germination time was determined according to Equation 1 and the germination rate according to Equation 2 (Bewley et al., 2013).

$\mathrm{AGT}=\Sigma\left(\mathrm{t}_{\mathrm{i}} \times \mathrm{n}_{\mathrm{i}}\right) / \Sigma \mathrm{n}$

(Eq. 1)
$\mathrm{GR}=1 / \mathrm{AGT}$

In which:

AGT $=$ Average germination time

$\mathrm{GR}=$ Germination rate

$\mathrm{n}_{\mathrm{i}}=$ number of normal seedlings on day $\mathrm{i}$;

$t_{i}=$ is the number of days from the start of the test.

\section{Seedling growth}

The test was performed with four replicates of 10 seeds each, which were distributed in rolls of paper towel moistened with 2.5 times the weight of the dry paper, with solutions of PEG 6000 , equivalent to the osmotic potentials of $-0.2,-0.4$ and $-0.6 \mathrm{MPa}$, besides the control with distilled water. At the end of the test (8th day after sowing) the seedlings were submitted to shoot and root measurements, which were separated and measured with the aid of a graduated ruler. The results were expressed in $\mathrm{cm}$ seedling ${ }^{-1}$ (Krzyzanowski et al., 2020).

Following length measurements, the seedlings had their shoots and roots separated and placed in an oven at $65{ }^{\circ} \mathrm{C}$, where they remained for 72 hours. Subsequently, the dry material was weighed in an analytical balance $(0.001 \mathrm{~g})$. The dry matter was expressed in $\mathrm{mg}$ seedling ${ }^{-1}$ (Krzyzanowski et al., 2020).

\section{Experimental design and statistical analysis}

The experiment was conducted in a randomized complete block design, in subdivided plots scheme, with four replications. In the plots were allocated the three irrigation depths and the osmotic potentials in a $3 \times 4$ factorial scheme, that is, three depths and four potentials. In the subplots were allocated the treatments of foliar application of $\mathrm{Si}$, at doses of $0 \mathrm{mM}$ (control) and $5 \mathrm{mM}$ of Si.

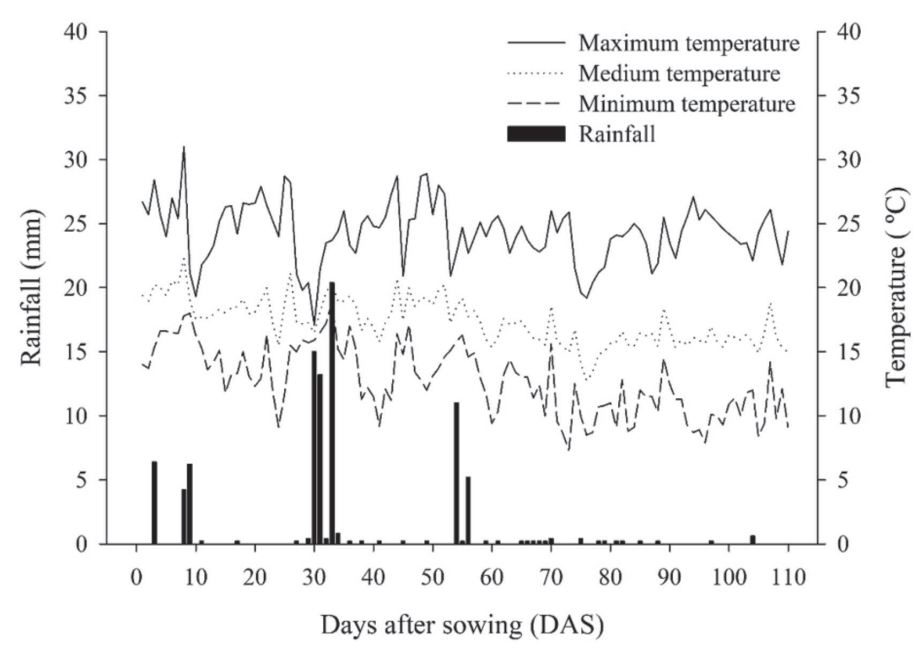

Figure 1: Rainfall distribution, maximum, average and minimum temperature during the wheat seed production period. Viçosa-MG, 2017.

Rev. Ceres, Viçosa, v. 68, n.4, p. 360-367, jul/aug, 2021 
Data were submitted to analysis of variance. The verification of the normality of the errors and of the homogeneity of variances was performed through the Shapiro-Wilk and Bartlett tests, respectively. The averages obtained for each irrigation depth were compared by the Tukey test ( $p \leq 0.05)$; the averages obtained for the osmotic potentials were submitted to regression analysis $(p \leq 0.05)$; and the averages obtained for the Si doses were compared by the F test ( $p \leq 0.05)$. Statistical analysis was performed using statistical software R (R Core Team, 2021).

\section{RESULTS AND DISCUSSION}

Germination of wheat seeds produced under different irrigation depths, and foliar application of silicon at 0 and $5 \mathrm{mM}$ of $\mathrm{Si}$, was negatively influenced by the osmotic potential (Figure 2A). It was observed a reduction in seed germination percentage, which initially was of values above $90 \%$ in the control potential $(0.0 \mathrm{MPa})$, to approximate values of $50 \%$ of germination in the most drastic potential, -0.6 MPa. This reduction shows the effect of water stress on germination of wheat seeds, which can be explained by its influence on the water absorption, which is compromised in low osmotic potentials and thus prevent the occurrence of events related to the germination process (Botelho \& Perez, 2001). Despite the drastic reduction observed in seed germination at potential $-0.6 \mathrm{MPa}$, it is considered that the seeds of cultivar BRS 264 used in this study present moderate tolerance to water stress during germination, since seed germination was still observed in the lowest potential, although this cultivar is classified in some works as sensitive to drought (Girotto et al., 2012).

No difference was observed in seed germination in the different osmotic potentials when comparing the different irrigation depths treatments and the doses of $\mathrm{Si}$ applied via foliar. Therefore, no beneficial effect of silicon was observed for increasing water stress tolerance during germination of wheat seeds (Figure 2A). However, Tavares et al. (2014) stated that the physiological quality of the seeds may not be directly related to silicon fertilization, but rather due to the improvement in plant development conditions, that is, plants that are more tolerant to both biotic and abiotic stresses produce seeds with higher physiological quality.

The germination speed was evaluated using the tests of first germination count, germination rate and average germination time (Figures 2B, 3A and B). A significant reduction of germination speed occurred, and null germination was observed for all treatments at the most extreme potential, $-0.6 \mathrm{MPa}$, on the $4^{\text {th }}$ day of the test.

The highest values for the germination rate were observed for the control treatment $(0.0 \mathrm{MPa})$. As the osmotic potential decreased, reduction in the germination rate of the seeds was observed. Lower values of average germination time were observed for the control. An increase in the values was observed according to the reduction of the osmotic potential, that is, the germination of the seeds was slower. There was no significant effect of the different irrigation depths treatments and of the two silicon treatments for any of the variables related to germination speed.

In very negative osmotic potentials, responses such as reduction in germination and its delaying are observed (Brito et al., 2016), which can lead to complete inhibition, as verified for the potential of $-0.6 \mathrm{MPa}$.

The water deficit usually influences the speed and percentage of seed germination (Bewley et al., 2013) and contributes to an increase in the time required for germination in this unfavorable condition. This may be
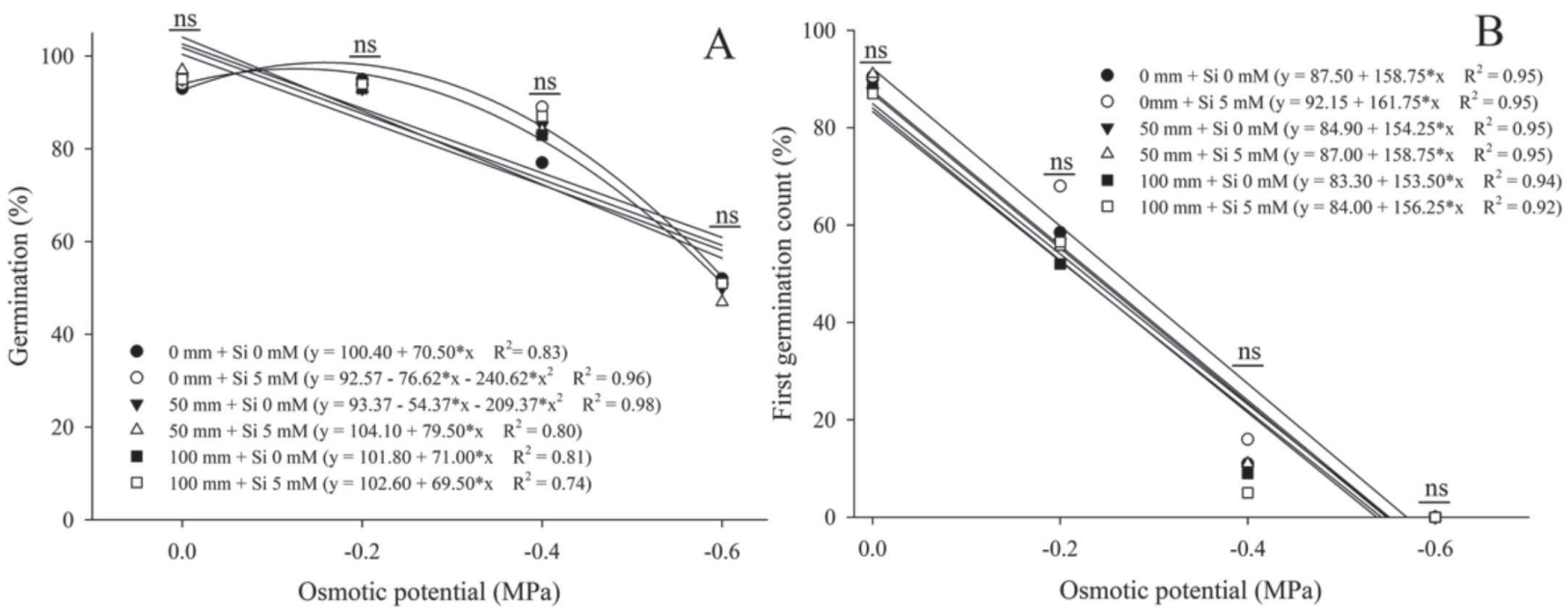

Figure 2: Germination (A) and first germination count (B) of wheat seeds from plants submitted to different irrigation depths from the anthesis, and two doses of silicon applied via foliar, as a function of the osmotic potential. * significant at $5 \%$ probability. ns not significant by the $\mathrm{F}$ test. The horizontal bars compare the different treatments within each osmotic potential. 
related to the time it takes for the seeds to develop adaptation mechanisms (Barroso, 2010). In reduced osmotic potentials, the process of seed imbibition occurs more slowly, and since the process of seed germination is dependent on water for the activation of the metabolic processes that lead to germination, water limitation reduces their speed germination and the increase in average germination time.

The reduction of the water potential in the germination substrate limits the water absorption by the seeds and causes a retardation of the metabolic processes that culminate with the germination (Botelho \& Perez, 2001). Thus, both germination (Figure 2) and germination speed (Figures 2B, 3A and B) were reduced with water stress, but no effects of foliar application of Si or of the different irrigation depths imposed on plants during seed maturation were observed.

No difference was observed between the different irrigation depths, at 0 and $5 \mathrm{mM}$ silicon doses, on the growth of seedlings under water deficit, when comparing the data of shoot length (Figure 4A) and root length (Figure $4 \mathrm{~B})$. On the other hand, there was an effect of the osmotic potential on the two variables, which showed reduction of the length with the reduction of the water potential.

The reduction of the osmotic potential, as well as affecting the percentage and the germination speed, as observed in this experiment, affects the growth of the seedlings due to the decrease in cell expansion (Taiz \& Zeiger, 2017). However, the reduction of shoot length was more intense when compared to that observed for root length.

This smaller root length reduction can be attributed to a rapid osmotic adjustment to allow turgor pressure to be restored. Thus, the potential gradient is resumed, with consequent water absorption and root growth (Hsiao \& $\mathrm{Xu}, 2000)$. In contrast, this osmotic adjustment in the leaves occurs slowly, which causes a decrease or stop in the increase of the cellular walls, causing less growth of the shoot. Therefore, the non-alteration of root growth under water deficiency conditions is a mechanism for adapting plants to this condition (Hsiao \& Xu, 2000; Magalhães-Filho et al., 2008).

Analogous behavior was found for seedling shoot (Figure C) and root (Figure D) dry matter. For these variables, no difference was observed between the evaluated treatments, but there was a reduction in the dry mass of the shoot, starting from the potential -0.2 MPa, which was more drastic than the reduction observed for the dry mass of the root. This result may also be related to the plant's strategy of adapting to the water deficiency condition, maintaining or increasing the flow of reserves to the root system to maintain its growth in search of water. Steiner et al. (2017) stated that, during the establishment stage of the plant, the allocation of dry matter to the root system appears to be a protection mechanism for the crop to tolerate a condition of lack of water.

In general, irrigation depth treatments and foliar application of silicon during the production of wheat seeds did not influence germination and initial seedling growth, as well as seed tolerance to water stress in the germination stage and initial seedling development. However, an important strategy used to better stimulate defenses and adaptability to drought is the simulation of a recovery period, through reapplication of water (de Macêdo et al., 2019; Chen et al., 2016). Thus, a simulation of a recovery period could be an alternative to better assess the effect
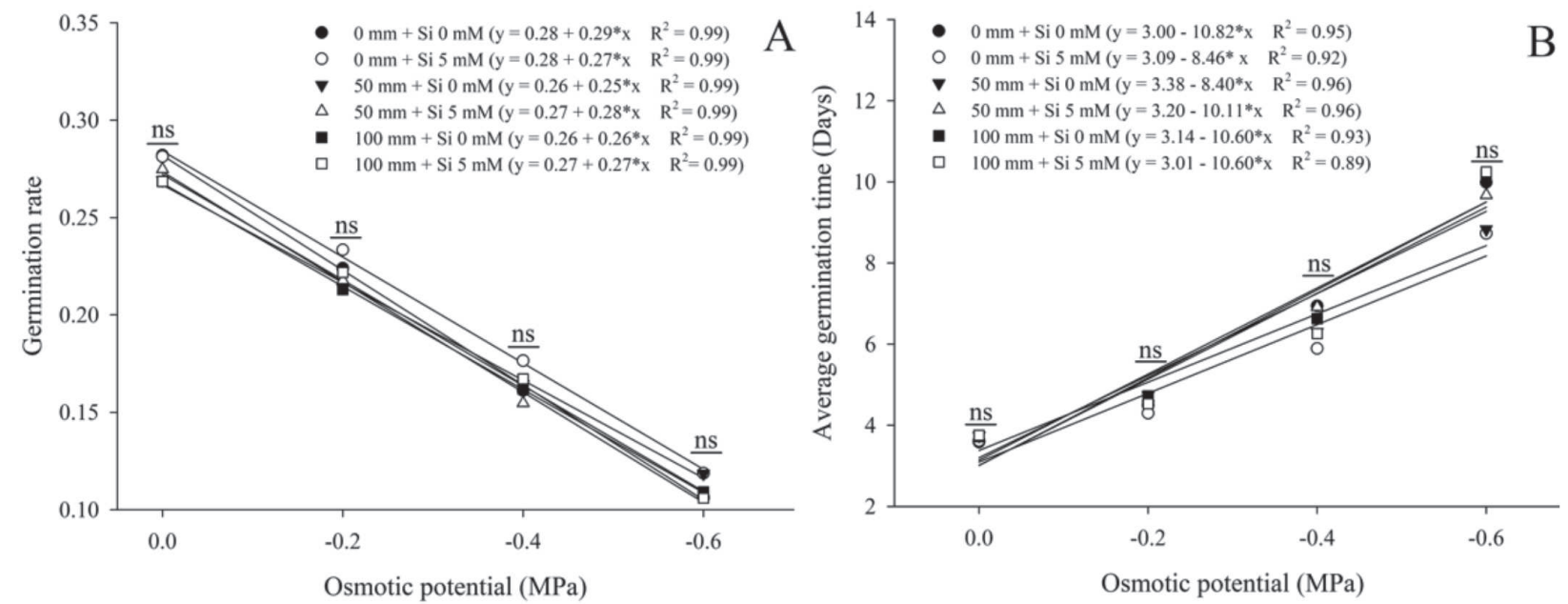

Figure 3: Germination rate (A) and average germination time (B) of wheat seeds from plants submitted to different irrigation depths from the anthesis, and two doses of silicon applied via foliar, as a function of the osmotic potential. * significant at 5\% probability. ns - not significant by the F test. The horizontal bars compare the different treatments within each osmotic potential. 

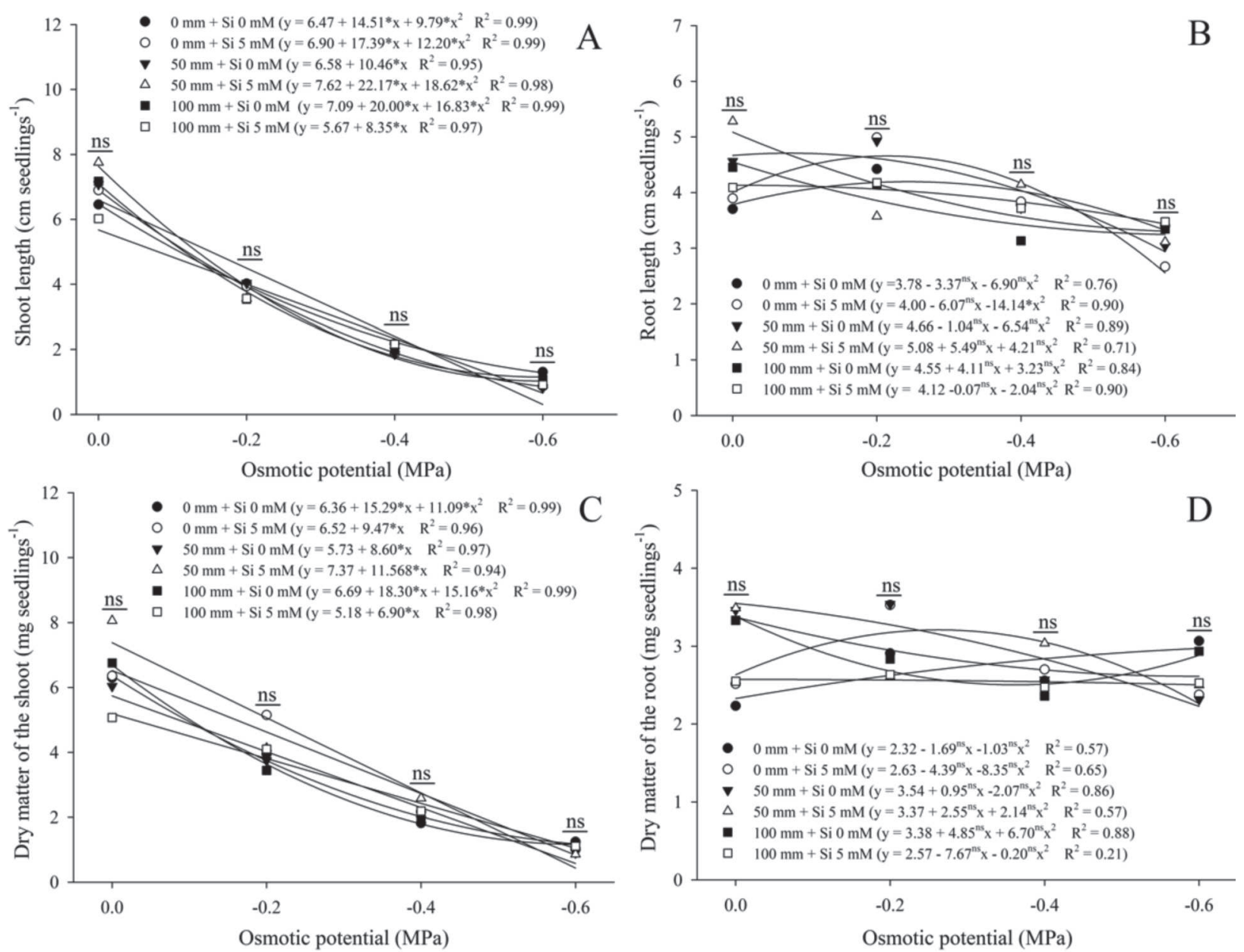

Figure 4: Shoot length (A), root length (B), dry matter of shoot (C) and root (D) of wheat seedlings from seeds produced in plants submitted to different irrigation depths from the anthesis, and two doses of silicon applied via foliar, as a function of the osmotic potential. * significant at $5 \%$ probability. ns - not significant by the $\mathrm{F}$ test. The horizontal bars compare the different treatments within each osmotic potential.

of tolerance on present study. On the other hand, seeds were sensitive to water stress simulated by PEG 6000 during germination, with reductions in germination and germination speed identified by germination tests, first germination count, germination rate and average germination time, as the potential osmotic reduced (Figures 2 and 3).

Seedling growth was also affected by water stress during germination of wheat seeds and seedling initial growth, which was more expressive in the shoot of the seedlings in relation to root growth (Figure 4). This was identified in the experiment by assessing the length of the shoot and the root and can be explained by the possible adaptation of the seedlings to the stress condition imposed.

\section{CONCLUSIONS}

The different irrigation depths in the seed maturation stage, as well as the foliar application of silicon in the wheat plants, did not influence the germination and initial seedling growth nor their tolerance to the condition of water stress during germination.

Wheat seeds of cultivar BRS 264 present moderate tolerance to water stress during germination, but there is a reduction in the number of normal seedlings and seedling growth with the increase of the stress level to the osmotic potential of $-0.6 \mathrm{MPa}$.

\section{ACKNOWLEDGEMENTS, FINANCIAL SUPPORT AND FULL DISCLOSURE}

The authors thank the FAPEMIG, CAPES and CNPq, for the financial support to the research. The authors declare that they have no conflict of interest.

\section{REFERENCES}

Acevedo FE, Peiffer M, Ray S, Tan CW \& Felton GW (2021) Silicon-mediated enhancement of herbivore resistance in agricultural crops. Frontiers in Plant Science, 12:1-16.

Allen RG, Pereira LS, Raes D \& Smith M (1998) Crop evapotranspiration - Guidelines for computing crop water requirement. Rome, FAO. 300p.

Rev. Ceres, Viçosa, v. 68, n.4, p. 360-367, jul/aug, 2021 
Andrade SRM, Santos JM, Tabosa DDS, Benedetti E, Albrecht J, Chagas J \& Só e Silva M (2015) Estudos de cultivares de trigo submetidas ao estresse hídrico em casa de vegetação. In: Reunião da comissão brasileira de pesquisa de trigo e triticale, Passo Fundo. Biotrigo Genética/Embrapa Trigo, 1-5.

Barroso CM, Franke LB \& Barros IBI (2010) Substrato e luz na germinação das sementes de rainha-do-abismo. Horticultura Brasileira, 28:236-240.

Bewley JD, Bradford KJ, Hilhorst HW \& Nonogaki H (2013) Seeds: Physiology of Development, Germination and Dormancy. $3^{\text {rd }}$ ed. New York, Springer. 392p.

Bilichak A \& Kovalchuk I (2016) Transgenerational response to stress in plants and its application for breeding. Journal of Experimental Botany, 67:2081-2092.

Botelho BA \& Perez SCJGA (2001) Estresse hídrico e reguladores de crescimento na germinação de sementes de canafístula. Scientia Agricola, 58:43-49.

Brasil (2009) Regras para análise de sementes. Brasília, MAPA/ ACS. 395p.

Brito CD, Loureiro MB, Ribeiro PR, Vasconcelos P, Fernandez LG \& Castro RD (2016) Osmoconditioning prevents the onset of microtubular cytoskeleton and activation of cell cycle and is detrimental for germination of Jatropha curcas L. seeds. Plan Biology, 18:1053-1057.

Bukhari MA, Ashraf MY, Ahmad R, Waraich EA \& Hameed M (2015) Improving drought tolerance potential in wheat (Triticum aestivum L.) through exogenous silicon supply. Pakistan Journal of Botany, 47:1641-1648.

Chen D, Wang S, Cao B, Cao D, Leng G, Li H, Yin L, Shan L \& Deng X (2016) Genotypic variation in growth and physiological response to drought stress and re-watering reveals the critical role of recovery in drought adaptation in maize seedlings. Frontiers in Plant Science, 6:1241-2016.

De Macêdo ÉC, Zonta JH, Melo YL, Melo ASD, Silva DCD \& Andrade WLD (2019) Changes in osmoregulatory metabolism of cotton genotypes during water deficit and recovery period. Revista Brasileira de Engenharia Agrícola e Ambiental, 23:607613

Dhanda SS, Sethi GS \& Behl RK (2004) Indices of drought tolerance in wheat genotypes at early stages of plant growth. Journal of Agronomy and Crop Science, 190:6-12.

Eskandari H \& Alizadeh-amraie A (2017) Evaluation of seed quality of wheat (Triticum aestivum) under water limition induced by a partial root-zone irrigation regime. Seed Science and Technology, 45:248-251.

Girotto L, Alves JD, Deuner S, Albuquerque ACS \& Tomazoni AP (2012) Tolerância à seca de genótipos de trigo utilizando agentes indutores de estresse no processo de seleção. Revista Ceres, 59:192-199.

Hsiao TC \& Xu LK (2000) Sensitivity of growth of roots versusleaves to water stress: biophysical analysis and relation to water transport. Journal of Experimental Botany, 51:1595-1616.

Hubbard M, Germida J \& Vujanovic V (2012) Fungal endophytes improve wheat seed germination under heat and drought stress. Botany, 90:137-149.

Kashif M (2011) Performance of wheat genotypes under osmotic stress at germination and early seedling growth stage. Sky Journal of Agricultural Research, 6:971-975.

Khan MIR, Ashfaque F, Chhillar H, Irfan M \& Khan NA (2021) The intricacy of silicon, plant growth regulators and other signaling molecules for abiotic stress tolerance: An entrancing crosstalk between stress alleviators. Plant Physiology and Biochemistry, 162:36-47.
Krzyzanowski FC, França-Neto JB, Gomes-Junior FG, Nakagawa J (2020) Testes de vigor baseados em desempenho de plântulas. In: Krzyzanowski FC, Vieira RD, Marcos Filho J \& França Neto JB (Eds.) Vigor de sementes: conceitos e testes. Londrina, ABRATES. p.79-140

Libardi V \& Costa M (1997) Consumo d'água da cultura do trigo (Triticum aestivum, L.). Revista da Faculdade de Zootecnia, Veterinária e Agronomia, 4:17-22.

Magalhães-filho JR, Amaral LRD, Machado DFSP, Medina CL \& Machado EC (2008) Deficiência hídrica, trocas gasosas e crescimento de raízes em laranjeira 'valência' sobre dois tipos de porta-enxerto Laranjeira "Valência" sobre dois tipos de portaenxertos. Bragantia, 67:75-82.

Marcos-filho J (2015) Fisiologia de sementes de plantas cultivadas. Londrina, ABRATES. 659p.

Monteiro JE (2009) Agrometeorologia dos cultivos: o fator meteorológico na produção agrícola. Brasília, INMET. 530p.

Nogueira RJ, Moraes JAPD, Burity HA \& Bezerra Neto E (2001) Alterações na resistência à difusão de vapor das folhas e relações hídricas em aceroleiras submetidas a déficit de água. Revista Brasileira de Fisiologia Vegetal, 13:75-87.

Pereira MD \& Lopes JC (2011) Germinação e desenvolvimento de plântulas de pinhão manso sob condições de estresse hídrico simulado. Semina Ciências Agrárias, 32:1837-1842.

$\mathrm{R}$ development core team (2021) R: A language and environment for statistical computing. Vienna, R Foundation for Statistical Computing. Available at: https://www.R-project.org/. Accessed on: January $31^{\text {th }}, 2018$.

Rao S, Du C, Li A, Xia X, Yin W \& Chen J (2019) Salicylic Acid Alleviated Salt Damage of Populus euphratica: A Physiological and Transcriptomic Analysis. Forests, 10:423.

Rauf M, Munir M, Hassan MU, Ahmad M \& Afzal M (2007) Performance of wheat genotypes under osmotic stress at germination and early seedling growth stage. African Journal of Biotechnology, 6:971-975.

Ribeiro AC (1999) Recomendação para o uso de corretivos e fertilizantes em Minas Gerais: 5a. aproximação. Viçosa, Comissão de Fertilidade do Solo do Estado de Minas Gerais. 359p.

Sarto MVM, Rampim L, Lana MDC, Rosset JS, Ecco M \& Wobeto JR (2014) Attributes of soil chemical and development of culture wheat for each silicon fertilization. Revista Agrarian, 7:390-400.

Segalin SR, Huth C, Rosa TODA, Pahins DB, Mertz LM, Nunes UR \& Martin TN (2013) Foliar application of silicon and the effect on wheat seed yield and quality. Journal of Seed Science, 35:86-91.

Steiner F, Zuffo AM, Zoz T, Zoz A \& Zoz J (2017) Drought tolerance of wheat and black oat crops at early stages of seedling growth. Revista de Ciências Agrárias, 40:576-585.

Taiz L, Zeiger E, Moller IM \& Murphy A (2017) Fisiologia $e$ desenvolvimento vegetal. $6^{\text {th }}$ ed. Porto Alegre, Artmed. 858p.

Tavares LC, Fonseca DÂR, Rufino CA, Oliveira SD, Brunes AP \& Villela FA (2014) Adubação silicatada em trigo: rendimento e qualidade de sementes. Revista de la Facultad de Agronomía, 113:94-99.

Toledo MZ, Castro GSA, Crusciol CAC, Soratto RP, Cavariani C, Ishizuka MS \& Picoli LB (2012) Aplicação foliar de silício e qualidade fisiológica de sementes de aveia-branca e trigo. Semina Ciências Agrárias, 33:1693-1702.

Tripathi DK, Singh S, Singh VP, Prasad SM, Dubey NK \& Chauhan DK (2017) Silicon nanoparticles more effectively alleviated UV-B stress than silicon in wheat (Triticum aestivum) seedlings. Plant Physiol/Biochem, 110:70-81. 
Villela FA, Doni filho L \& Sequeira EL (1991) Tabela de potencial osmótico em função da concentração de polietileno glicol 6000 e da temperatura. Pesquisa Agropecuária Brasileira, 26:19571968.

Walter J, Nagy L, Hein R, Rascher U, Beierkuhnlein C, Willner E \& Jentsch A (2011) Do plants remember drought? Hints towards a drought-memory in grasses. Environmental and Experimental Botany, 71:34-40
Yagmur M \& Kaydan D (2008) Alleviation of osmotic stress of water and salt in germination and seedling growth of triticale with seed priming treatments. African Journal of Biotechnology, $7: 2156-2162$ 